\title{
STUDI DESKRIPTIF MENGENAI PSYCHOLOGICAL WELL-BEING PADA LANSIA DI TAMAN LANSIA AN-NABA TANGGULANGIN GUNUNGKIDUL
}

\author{
Sukadari ${ }^{(1)}$, Mahilda Dea Komalasari ${ }^{(2)}$, Ahmad Mabruri Wihaskoro ${ }^{(3)}$ \\ PIPS \\ Universitas PGRI Yogyakarta \\ E-mail: sukadari@upy.ac.id
}

\begin{abstract}
Abstrak
Masa lanjut usia merupakan masa dimana seseorang mengalami berbagai kemunduran fungsi, baik fisiologis, psikologis, maupun sosial. Penelitian ini bertujuan untuk membuat sebuah deskripsi mengenai kesejahteraan psikologis lansia serta memperoleh data empiris mengenai Psychological Well-Being kaum lansia jamaah taman lansia An-Naba. Penelitian ini menggunakan metode penelitian kualitatif dengan strategi penelitian studi kasus intrinsik dan model penelitian deskriptif pada tiga subyek lanjut usia. Penelitian ini menggunakan alat ukur Psychological Well-Being Scale (PWBS) dari Ryff (1989). Hasil analisis data menunjukkan bahwa ketiga subyek lansia dengan berbagai hambatan dan perkembangan yang harus dipenuhinya dapat mengatasi hal-hal tersebut apabila memenuhi dimensi-dimensi dari Psychological Well-Beingnya. Ketiga subyek mampu memenuhi dimensi-dimensi yang terkait dengan Psychological Well-Being tersebut. Setiap subyek mampu menerima kondisinya sebagai lansia, mampu menghayati keberfungsian hidupnya dalam menerima kelemahandan kesulitan yang dihadapi sebagai lansia serta dapat mencapai tujuan hidup dengan mengembangkan potensi yang dimiliki. Dimensi autonomi menjadi dimensi yang dominan, sedangkan self acceptance menjadi dimensi yang kurang dominan pada Psychological Well-Being.
\end{abstract}

Kata Kunci: psychological well-being, lansia, taman lansia

\begin{abstract}
Old age is a time when someone experiences a setback of function, both physiological, psychological, and social. This study aims to make a description of the psychological well-being of the elderly and obtain empirical data about the Psychological Well-Being of the elderly in the elderly An-Naba elderly park. This research uses qualitative research methods with intrinsic case study research strategies and descriptive research models on three elderly subjects. This study uses the Psychological Well-Being Scale (PWBS) measurement tool from Ryff (1989). The results of data analysis show that the three elderly subjects with various obstacles and developments that must be fulfilled can overcome these things if they meet the dimensions of their Psychological Well-Being. All three subjects were able to fulfill the dimensions associated with the Psychological Well-Being. Each subject is able to accept his condition as an elderly, able to live the functioning of his life in accepting the weaknesses and difficulties faced as elderly and can achieve life goals by developing their potential. The autonomy dimension becomes the dominant dimension, while self acceptance becomes the less dominant dimension in Psychological WellBeing.
\end{abstract}

Keywords: Psychological Well-Being, old age, elderly park

\section{Info Artikel}

Diterima Oktober 2019, disetujui November 2019, diterbitkan Desember 2019 


\section{PENDAHULUAN}

Masa remaja adalah masa pencarian jati diri. Menurut psikologi,remaja adalah suatu periode transisi dari dewasa awal anak anak hingga masa awal dewasa, yang dimasuki pada usia kira kira 10 hingga 12 tahun dan berakhir pada usia 18 tahun hingga 22 tahun. Sedangkan menurut santrock $(2003 ; 26)$ bahwa remaja(adolescene)diartikan sebagai masa perkembangan transisi antara masa anak dan masa dewasa yang mencakup perubahan biologis,kognitif,sosial emosional.batasan usia remaja yang umum digunakan oleh para ahli adalah antara 12 hingga 21 tahun .Siswa pada taraf Sekolah Menengah Pertama termasuk kategori remaja

Salah satu indikator keberhasilan pembangunan adalah semakin meningkatnya usia harapan hidup penduduk, yang menyebabkan jumlah penduduk lanjut usia (lansia) terus meningkat dari tahun ke tahun (BPS, 2008). Indonesia masuk dalam lima besar Negara dengan jumlah lansia terbanyak di dunia (BPS, 2015). Berdasarkan sensus penduduk yang dilakukan Badan Pusat Statistik (BPS) pada tahun 2010, jumlah lansia di Indonesia yaitu 18,1 juta jiwa (7,6\% dari total penduduk), sedangkan pada tahun 2014, jumlahnya menjadi 18,781 juta jiwa dan diperkirakan pada tahun 2025, jumlahnya akan mencapai 36 juta jiwa (BPS, 2015). Jumlah ini akan semakin bertambah setiap tahun, dikarenakan adanya pembangunan kesehatan dan kondisi sosial ekonomi yang semakin baik di Indonesia.

Dilihat dari wilayah kabupaten/kota di DIY, jumlah lansia terlantar terbanyak ada di Kabupaten Gunungkidul yakni sebanyak 12.564 jiwa pada tahun 2011 dan 15.422 jiwa di tahun 2012, serta 18.420 jiwa di tahun 2018. Jumlah lansia terlantar di Kabupaten Gunungkidul ini mencapai $41,45 \%$ dari seluruh lansia terlantar di DIY (Ridarineni, 2013). Warga lansia yang terlantar di Gunungkidul menempati jumlah tertinggi dari keseluruhan Penyandang Masalah Kesejahteraan Sosial (PMKS) di wilayah ini. Adapun total jumlah PMKS di Gunungkidul sebanyak 33.253 jiwa. Persebaran lansia terlantar di Gunungkidul paling banyak yakni 1.522 jiwa di Rongkop, 1.076 jiwa di Playen, 965 jiwa di Ponjong dan 849 jiwa di Karangmojo (Kusumo, 2018; Putri, 2018).

Lansia merupakan masa dimana kondisi fisik mulai menurun dan tidak produktif lagi, sehingga tidak jarang dijumpai para lansia yang gagal menangkap isi pembicaraan orang lain sehingga mudah menimbulkan perasaan tersinggung, tidak dihargai, dan kurang percaya diri. Permasalahan lain dari lansia yang tinggal di Gunungkidul yaitu terjangkitnya penyakit degeneratif seperti hipertensi dan rheumatoid arthritis. Penyakit tersebut disebabkan oleh beberapa faktor, salah satunya adalah gaya hidup yang tidak sehat (Asfriyati, 2003). Hasil Riset Kesehatan Dasar (Riskesdas) tahun 2010 menunjukkan bahwa angka hipertensi lansia di Kabupaten Gunungkidul tercatat 12,21\% (DIY sebesar 8,53\%) dan penyakit sendi lansia sebesar 39,68\% (DIY sebesar 27,03\%) (Kemenkes, 2013; Kemenkes, 2014). Masalah kesehatan pada lansia berawal dari kemunduran sel-sel tubuh, sehingga fungsi dan daya tahan tubuh menurun serta faktor resiko terhadap penyakitpun meningkat. Masalah kesehatan yang sering dialami lansia adalah malnutrisi, gangguan keseimbangan, kebingungan mendadak. Selain itu, beberapa penyakit yang sering terjadi pada lansia antara lain hipertensi, gangguan pendengaran dan penglihatan, demensia, osteoporosis (Kemenkes, 2015).

Data kepolisian Gunungkidul menunjukkan bahwa angka bunuh diri naik semenjak awal tahun 2015. Selama bulan Mei 2015, terdapat tiga kasus bunuh diri yang terjadi di Gunung Kidul, dua kasus di Kecamatan Wonosari, dan satu kasus di Kecamatan Ponjong. Tindakan bunuh diri tersebut dilakukan oleh lansia di atas 60 
tahun dengan ciri menderita penyakit kronis dan depresi (Sucahyo, 2017). Kasus depresi hingga bunuh diri yang terjadi pada lansia disebabkan oleh emosi negatif atau emosi tidak menyenangkan yang dirasakan oleh lansia sebagai efek dari ketidakmampuan lansia dalam mengatasi masalah yang dihadapinya. Keadaan ini dapat menyebabkan individu yang bersangkutan merasa tidak puas dan tidak sejahtera di dalam kehidupannya.

Menurut Psikiater sekaligus dokter spesialis kesehatan jiwa dari Rumah Sakit Umum Daerah (RSUD) Wonosari, Gunungkidul, Ida Rochmawati (Herman, 2014), terdapat indikasi yang kuat bahwa kasus bunuh diri lansia disebabkan oleh permasalahan mental. Penyakit degenaratif yang disebabkan oleh bertambahnya usia dapat menyebabkan depresi, ditambah lagi perasaan kesepian dan perasaan menjadi beban bagi usia produktif. Hal tersebut akan bertambah buruk ketika banyak keluarga yang mengabaikan kesejahteraan para lansia dengan membiarkan lansia hidup sendiri.

Menurut Kepala Bidang Rehabilitasi Sosial, Dinas Sosial (Dinsos), Gunungkidul, Irfan Ratnadi (Kusumo, 2018) banyak faktor sebenaranya yang menyebabkan angka lansia terlantar menjadi tinggi, yaitu disebabkan karena umur harapan hidup Gunungkidul tinggi dibarengi dengan banyak sanak keluarganya yang keluar merantau sehingga banyak lansia hidup sendiri dengan keterbatasan. Selain itu juga disebabkan karena perubahan struktur kehidupan masyarakat yang menginjak usia lanjut seperti sudah tidak bekerja, menyebabkan adanya kebutuhan akan interaksi sosial. Berdasarkan penelitian yang dilakukan oleh Vaznoniene (2016), kaum lansia membutuhkan dukungan sosial dari keluarga dan pemerintah terutama dalam hal penyediaan fasilitas sosial seperti pelayanan kesehatan.

Adapun undang-undang yang mengatur kebijakan mengenai lansia, yaitu UndangUndang No. 13 Tahun 1998 tentang Kesejahteraan Lanjut Usia (Presiden RI, 1998). Dalam pasal 1 ayat 2 dinyatakan bahwa yang dimaksud dengan lansia adalah seseorang yang berusia 60 tahun ke atas. Selanjutnya pada pasal 5 dan 6 disebutkan bahwa lansia mempunyai hak dan kewajiban yang sama sebagai warga negara Indonesia dalam kehidupan bermasyarakat, berbangsa dan bernegara. Berdasarkan UU No. 36 Tahun 2009 tentang Kesehatan (Presiden RI, 2009), upaya pemeliharaan kesehatan bagi lansia harus ditujukan untuk menjaga agar tetap hidup sehat dan produktif secara sosial maupun ekonomis. Berdasarkan undang-undang tersebut, Pemerintah wajib menjamin tersedianya layanan kesehatan dan memfasilitasi kelompok lansia untuk dapat tetap hidup mandiri dan produktif. Oleh karena itu, kaum lansia perlu memperoleh kegiatan pemberdayaan.

Kegiatan pemberdayaan lansia, khususnya dalam bidang kesehatan tentu melibatkan peran serta dari pemerintah, swasta, dan masyarakat. Selain itu, harus ada koordinasi yang efektif antara lintas program terkait di lingkungan Kementerian Kesehatan dan organisasi profesi dalam upaya peningkatan kesehatan lansia. Menurut Irfan (Kusumo, 2018), upaya dari Pemkab Gunungkidul untuk mengurangi jumlah lansia terlantar tidak hanya melalui bantuan saja, melainkan juga ada program pemindahan ke panti jompo. Namun, hal tersebut justru sering mendapat penolakan dari lansia dengan alasan ingin bertahan hidup dengan kemampuan dan keterbatasan yang mereka miliki. Para lansia tidak mau merepotkan banyak orang terkait dengan kelangsungan hidup mereka. Memiliki kebahagiaan dan ketenangan lahir batin di masa tua adalah impian setiap orang. Karenanya, tidak sedikit para lansia yang ingin menghabiskan masa tuanya untuk mendekatkan diri kepada Allah, demi meraih ketenangan dan akhir hidup yang baik (husnul khatimah). 
Prof. Dr. dr. Akmal Taher, SpU (K) (2015) menyampaikan bahwa pentingnya upaya promotif dan preventif yang dilakukan untuk mengurangi kerentanan lansia terhadap sakit. Upaya yang dikembangkan untuk mendukung kegiatan pemberdayaan lansia tersebut antara lain melalui pengembangan rintisan kampung ramah lansia melalui taman lansia yang menyediakan sarana dan prasarana yang ramah bagi lansia.

Taman Lansia merupakan sekolah yang diperuntukkan khusus untuk lansia sebagai wadah kreativitas serta sarana pertemuan dan interaksi bagi sesama kaum lansia. Kondisi demikian sesuai dengan Undang-undang Nomor 13 Tahun 1998 Tentang Kesejahteraan Lanjut Usia, khususnya pada pasal 17 ayat 2, bahwa diperlukan penyediaan fasilitas rekreasi dan olahraga khusus bagi masyarakat lansia (Presiden RI, 1998). Taman lansia ini bertujuan untuk mengisi kegiatan positif pada masa lansia dalam rangka meningkatkan kualitas hidup di usia lanjut, serta mewujudkan lansia tangguh. Lansia tangguh adalah upaya agar meskipun telah berusia di atas 60 sampai 70 tahun lansia tetap produktif. Yang dibutuhkan dari lansia adalah ditekankan pada kebijaksanaannya atau otak, bukan otot. Kaum lansia akan diberikan berbagai kegiatan pemberdayaan dan pelatihan, sehingga masih bisa aktif setelah pensiun.

Taman lansia yang dikembangkan harus berbasis pada pendekatan khusus. Salah satu pendekatan yang tepat untuk menangani lansia yaitu psichologycal well-being (PWB). Diener \& Eid (2006) menggambarkan pengalaman internal yang dialami oleh kaum lansia tersebut sebagai Psychological Well-Being (PWB). PWB mencakup kepuasan hidup secara keseluruhan dan domain-domain kehidupan seperti kesehatan, keuangan, hubungan sosial, rekreasi diri dan keluarga, juga meliputi perbandingan personal mengenai pengalaman masa lalu dan masa kini, serta perbandingan personal dengan individu lain dalam kelompok usia yang sama (Mohanty, Gangil, \& Kumar, 2012). PWB memiliki kemampuan generatif yang membawa sejumlah efek menguntungkan seperti kesehatan yang lebih baik.

Program kemitraan masyarakat ini berperan dalam membantu kaum lansia di Pedukuhan Tanggulangin dalam pelayanan psikologis lansia, diantaranya pemantauan kesehatan usia lanjut dan melakukan kegiatan penyuluhan kesehatan pada masyarakat dan kelompok warga usia lanjut. Tujuan dari program kemitraan masyarakat ini adalah meningkatkan pengetahuan masyarakat mengenai pentingnya memberdayakan dan mengoptimalkan potensi lansia, meningkatkan kemampuan masyarakat mengenai cara memberdayakan dan mengoptimalkan potensi lansia, meningkatkan kesadaran dari setiap individu untuk menjaga kesehatan dan menyiapkan hari tua dengan sebaik dan sedini mungkin dan gerakan sehat sampai memasuki lanjut usia, serta meningkatkan kemandirian para lansia.

Adapun manfaat yang dapat diambil dari Program Kemitraan Masyarakat ini yaitu sebagai sarana untuk menambahan wawasan dan pengetahuan tentang cara memberdayakan dan mengoptimalkan potensi lansia, sebagai wadah yang memungkinkan para lansia untuk berkumpul, berdiskusi, saling membantu, serta memotivasi dalam memasuki usia lanjut. Selain itu, manfaatnya bagi kaum lansia Pedukuhan Tanggulangin yaitu menjadi Pedukuhan yang lebih peduli akan lansia. Adapun manfaat bagi pengabdi yaitu dapat menambah wawasan dan pengalaman dalam memberikan pelatihan terkait pengembangan rintisan kampung ramah lansia melalui taman lansia berbasis psychological well-being, serta menambah wawasan dan pengetahuan dalam menentukan strategi penggunaan pendekatan yang tepat dan sesuai dengan tingkat pengetahuan dan perilaku masyarakat Pedukuhan Tanggulangin dalam memberdayakan dan mengoptimalkan potensi lansia. 
Upaya tersebut perlu diwujudkan dengan berbagai kegiatan yang dapat meningkatkan kesehatan lansia, serta menyediakan fasilitas publik yang mendukung lansia bisa berkarya. Harapan dari didirikannya taman lansia berbasis psychological well-being ini adalah, para lansia lebih sehat, sehingga tidak bergantung sepenuhnya kepada anggota keluarganya. Di samping itu, keluarga yang memiliki lansia juga memiliki pengetahuan dan keterampilan dalam merawat dan membahagiakan lansia baik secara fisik maupun psikologis.

\section{METODE PENELITIAN}

Metode penelitian yang digunakan dalam penelitian ini adalah metode kualitatif dengan tipe penelitian studi kasus. Studi kasus berorientasi analisis mendalam terhadap suatu kasus dengan mengungkapkan sebanyak mungkin faktor yang menghasilkan manifestasi tertentu. Beberapa tipe unit yang dapat diteliti dalam bentuk studi kasus antara lain individu-individu, karakteristik atau atribut dari individu-individu, aksi dan interaksi, peninggalan atau artefak perilaku, setting, serta peristiwa atau insiden tertentu. Studi kasus intrinsik dilakukan untuk memahami secara utuh suatu kasus, tanpa harus dimaksudkan untuk menghasilkan konsep-konsep atau teori dan tanpa upaya menggeneralisasi.

Subyek dalam penelitian ini memiliki karakteristik sebagai berikut: lansia berusia 60 tahun atau lebih, ikut dalam kegiatan persekutuan lansia, bergabung atas inisiatif sendiri dan menikmati keterlibatannya dalam kegiatan di persekutuan lansia, dan bersedia menjadi subyek penelitian.

Instrumen penelitian yang digunakan adalah panduan wawancara yang disusun berdasarkan enam dimensi dari psychological well-being dari Ryff (1989) yaitu penerimaan diri, hubungan positif dengan orang lain, otonomi, penguasaan lingkungan, pertumbuhan pribadi dan tujuan hidup.

Data yang dikumpulkan berdasarkan hasil wawancara dengan ketiga subyek, kemudian dianalisis menggunakan teknik analisis tematik. Analisis tematik adalah suatu proses yang memungkinkan penerjemahan gejala atau informasi kualitatif menjadi data kualitatif sesuai dengan kebutuhan peneliti. Penggunaan analisis tematik memungkinkan peneliti menemukan 'pola' yang pihak lain tidak melihatnya secara jelas. Setelah tema ditemukan (seeing), dilakukan klasifikasi atau meng-encode pola tersebut (seeing as) dengan memberi label, definisi, atau deskripsi.

\section{HASIL PENELITIAN DAN PEMBAHASAN}

Hasil penelitian ditunjukkan dalam table 1 sebagai berikut, 


\begin{tabular}{|c|c|c|c|}
\hline \multicolumn{4}{|c|}{$\begin{array}{c}\text { Tabel } 1 . \\
\text { Hasil Wawancara }\end{array}$} \\
\hline Indikator & Subyek 1 & Subyek 2 & Subyek 3 \\
\hline \multicolumn{4}{|c|}{ Dimensi Penerimaan Diri } \\
\hline $\begin{array}{l}\text { Sikap terhadap } \\
\text { diri sendiri }\end{array}$ & $\begin{array}{ll}\text { - } & \text { Memandang } \\
& \text { positif diri } \\
& \text { sendiri. } \\
\text { - } & \text { Sangat disiplin. } \\
\text { - } & \text { Mampu } \\
& \text { menerima kritik } \\
& \text { dan mengelola } \\
& \text { emosi negatif. } \\
\end{array}$ & $\begin{array}{ll}\text { - } & \text { Memandang } \\
& \text { positif diri } \\
\text { sendiri. } \\
\text { - } & \text { Disiplin. } \\
\text { - } & \text { Mampu } \\
& \text { menerima kritik } \\
& \text { dan mengelola } \\
& \text { emosi negatif. } \\
\end{array}$ & $\begin{array}{ll}\text { - } & \text { Memandang } \\
\text { positif diri } \\
\text { sendiri. } \\
\text { - } & \text { Perfeksionis. }\end{array}$ \\
\hline Kelebihan Diri & $\begin{array}{l}\text { - } \text { Pekerja keras } \\
\text { - } \text { Selalu } \\
\text { bersyukur } \\
\text { kepada Tuhan. } \\
\text { - } \text { Berpendirian } \\
\text { kuat. } \\
\text { - Mampu } \\
\text { menerapkan } \\
\text { disiplin. } \\
\text { - Mandiri } \\
\text { - Percaya diri. }\end{array}$ & $\begin{array}{ll}\text { - } & \text { Gigih bekerja } \\
\text { - } & \text { Selalu bersyukur } \\
& \text { kepada Tuhan. } \\
\text { - } & \text { Berpendirian kuat } \\
\text { - } & \text { Mampu } \\
& \text { menerapkan } \\
& \text { disiplin. } \\
\text { - } & \text { Mandiri. } \\
\text { - } & \text { Memiliki empati } \\
& \text { yang tinggi }\end{array}$ & $\begin{array}{ll}\text { - } & \text { Tekun dalam } \\
\text { belajar dan } \\
\text { bekerja. }\end{array}$ \\
\hline Kekurangan diri & - & - & - \\
\hline $\begin{array}{l}\text { Sikap terhadap } \\
\text { masa lalu }\end{array}$ & $\begin{array}{l}\text { Menyadari } \\
\text { keadaan masa } \\
\text { lalu dan } \\
\text { memperbaikiny } \\
\text { a di masa } \\
\text { sekarang. } \\
\end{array}$ & $\begin{array}{ll} & \text { Menyadari } \\
\text { kemandiriannya } \\
\text { berasal dari } \\
\text { pengalaman masa } \\
\text { lalu. }\end{array}$ & 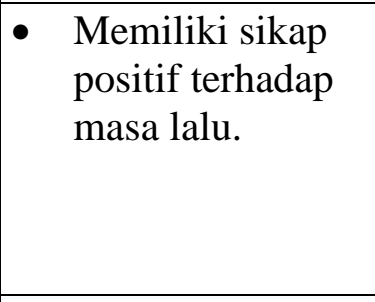 \\
\hline $\begin{array}{l}\text { Sikap terhadap } \\
\text { kondisi saat ini } \\
\text { (lansia) }\end{array}$ & $\begin{array}{ll}\text { - } & \text { Menerima } \\
\text { perubahan } \\
\text { fungsi tubuh. } \\
\text { - } \text { Menyadari } \\
\text { kematian. } \\
\text { - Mendekatkan } \\
\text { diri kepada } \\
\text { Tuhan. } \\
\text { - Menghargai dan } \\
\text { menjaga } \\
\text { kesehatannya } \\
\text { dengan } \\
\text { menerapkan } \\
\text { pola hidup sehat } \\
\text { dan olahraga } \\
\end{array}$ & $\begin{array}{ll}\text { - } & \text { Menerima } \\
\text { perubahan fungsi } \\
\text { tubuh. } \\
\text { - } \\
\text { Mendekatkan diri } \\
\text { kepada Tuhan. } \\
\text { Menghargai dan } \\
\text { menjaga } \\
\text { kesehatannya } \\
\text { dengan } \\
\text { menerapkan pola } \\
\text { hidup sehat dan } \\
\text { olahraga rutin. } \\
\text { Pasrah kepada } \\
\text { Tuhan. }\end{array}$ & $\begin{array}{ll}\text { - } & \text { Mendekatkan diri } \\
\text { kepada Tuhan. } & \text { Menghargai dan } \\
\text { menjaga } & \\
\text { kesehatannya } \\
\text { dengan } \\
\text { menerapkan pola } \\
\text { hidup sehat dan } \\
\text { olahraga rutin. } \\
\text { Bersikap tidak } \\
\text { terhambat dengan } \\
\text { kondisi fisik masa } \\
\text { tuanya. }\end{array}$ \\
\hline & & $\bar{F}$ & an \\
\hline
\end{tabular}




\begin{tabular}{|c|c|c|c|}
\hline & $\begin{array}{ll}\text { - } & \text { Putin. } \\
\text { Pasrah kepada } \\
\text { Tuhan. } \\
\text { - Bersikap tidak } \\
\text { terhambat } \\
\text { dengan kondisi } \\
\text { fisik masa } \\
\text { tuanya. }\end{array}$ & $\begin{array}{l}\text { - Bersikap tidak } \\
\text { terhambat dengan } \\
\text { kondisi fisik masa } \\
\text { tuanya. }\end{array}$ & \\
\hline \multicolumn{4}{|c|}{ Dimensi Hubungan Positif dengan Orang Lain } \\
\hline $\begin{array}{l}\text { Memiliki } \\
\text { hubungan yang } \\
\text { hangat dengan } \\
\text { orang lain }\end{array}$ & 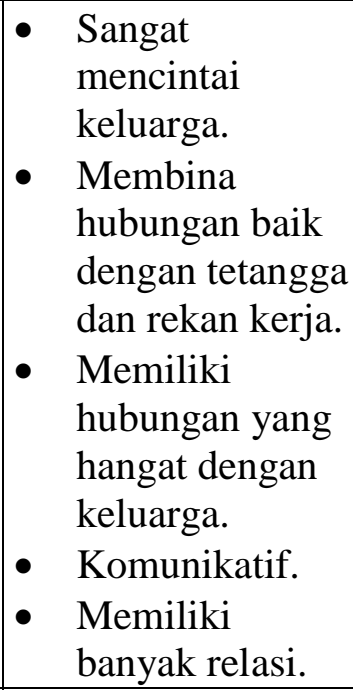 & $\begin{array}{l}\text { - Sangat mencintai } \\
\text { keluarga. } \\
\text { Membina } \\
\text { hubungan baik } \\
\text { dengan tetangga } \\
\text { dan rekan kerja. } \\
\text { - Memiliki } \\
\text { hubungan yang } \\
\text { hangat dengan } \\
\text { keluarga. } \\
\text { Komunikatif. }\end{array}$ & $\begin{array}{l}\text { - Sangat mencintai } \\
\text { keluarga. } \\
\text { Membina } \\
\text { hubungan baik } \\
\text { dengan tetangga } \\
\text { dan relasi kerja. } \\
\text { Memiliki } \\
\text { hubungan yang } \\
\text { hangat dengan } \\
\text { keluarga. } \\
\text { Komunikatif. }\end{array}$ \\
\hline $\begin{array}{l}\text { Hubungan saling } \\
\text { percaya dengan } \\
\text { orang lain. }\end{array}$ & $\begin{array}{ll}\text { - } & \text { Terbuka } \\
\text { - } & \text { Dipercaya } \\
\text { untuk menjadi } \\
\text { pemimpin } \\
\text { dalam beberapa } \\
\text { organisasi. }\end{array}$ & $\begin{array}{ll}\text { - } & \text { Tertutup } \\
\text { - } & \text { Dipercaya untuk } \\
\text { menjadi } \\
\text { pemimpin dalam } \\
\text { beberapa } \\
\text { organisasi. }\end{array}$ & - Tertutup \\
\hline $\begin{array}{l}\text { Mengerti rasa } \\
\text { saling memberi } \\
\text { dan menerima }\end{array}$ & $\begin{array}{l}\text { Ringan tangan } \\
\text { membantu } \\
\text { orang lain atau } \\
\text { tetangga yang } \\
\text { membutuhkan } \\
\text { bantuannya. }\end{array}$ & $\begin{array}{l}\text { Ringan tangan } \\
\text { membantu orang } \\
\text { lain atau tetangga } \\
\text { yang } \\
\text { membutuhkan } \\
\text { bantuannya. }\end{array}$ & $\begin{array}{l}\text { - Ringan tangan } \\
\text { membantu orang } \\
\text { lain atau tetangga } \\
\text { yang } \\
\text { membutuhkan } \\
\text { bantuannya. }\end{array}$ \\
\hline
\end{tabular}




\begin{tabular}{|c|c|c|c|}
\hline $\begin{array}{l}\text { Mampu } \\
\text { berempati, } \\
\text { menunjukkan } \\
\text { afeksi dan } \\
\text { keintiman }\end{array}$ & 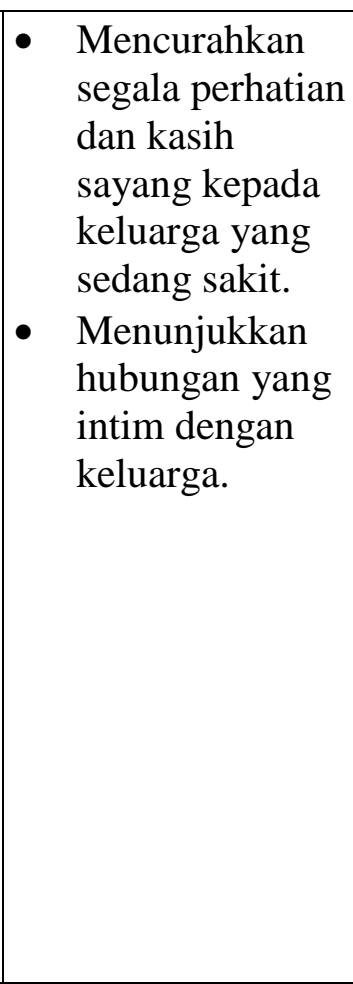 & $\begin{array}{l}\text { Menunjukkan } \\
\text { empati kepada } \\
\text { masalah anak- } \\
\text { anaknya. } \\
\text { - } \\
\text { Mencurahkan } \\
\text { segala perhatian } \\
\text { dan kasih sayang } \\
\text { kepada keluarga } \\
\text { yang sedang sakit. } \\
\text { Menunjukkan } \\
\text { hubungan yang } \\
\text { intim dengan } \\
\text { keluarga. }\end{array}$ & $\begin{array}{l}\text { Menunjukkan } \\
\text { empati kepada } \\
\text { masalah anak- } \\
\text { anaknya. } \\
\text { - Mencurahkan } \\
\text { segala perhatian } \\
\text { dan kasih sayang } \\
\text { kepada keluarga } \\
\text { yang sedang sakit. } \\
\text { Mendengarkan } \\
\text { keluh kesah } \\
\text { teman-temannya } \\
\text { ketika sedang } \\
\text { dalam masalah } \\
\text { dan berusaha } \\
\text { membantunya. } \\
\text { Menunjukkan } \\
\text { hubungan yang } \\
\text { intim dengan } \\
\text { keluarga. }\end{array}$ \\
\hline \multicolumn{4}{|c|}{ Dimensi Otonomi } \\
\hline $\begin{array}{l}\text { Sikap mandiri } \\
\text { terhadap } \\
\text { penyelesaian } \\
\text { masalah sehari- } \\
\text { hari. }\end{array}$ & 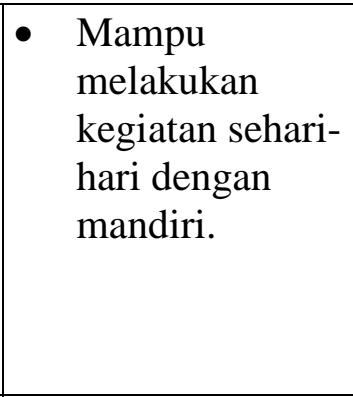 & $\begin{array}{ll}\text { - } & \text { Mampu } \\
\text { melakukan } \\
\text { kegiatan sehari- } \\
\text { hari dengan } \\
\text { mandiri. }\end{array}$ & 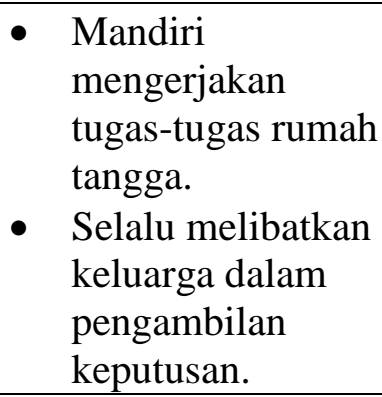 \\
\hline $\begin{array}{l}\text { Mengelak dari } \\
\text { tekanan berpikir }\end{array}$ & 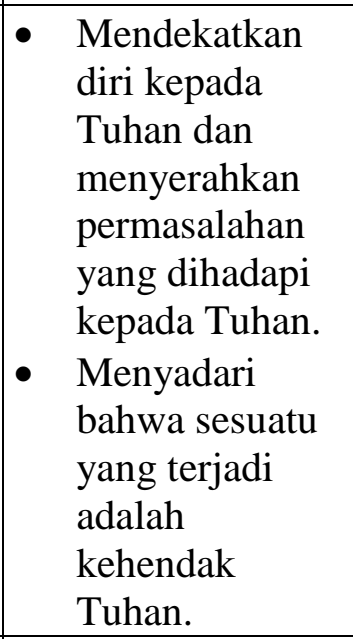 & 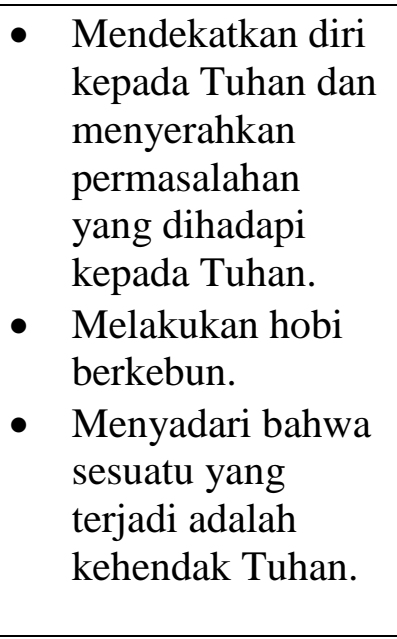 & $\begin{array}{ll}\text { - } & \text { Mencurahkan } \\
\text { perasaannya pada } \\
\text { keluarga terdekat. } \\
\text { - } \text { Melakukan } \\
\text { aktivitas yang } \\
\text { menyenangkan } \\
\text { sebagai bentuk } \\
\text { pengelakan dari } \\
\text { tekanan sosial. }\end{array}$ \\
\hline $\begin{array}{l}\text { Mengevaluasi } \\
\text { berdasar standar } \\
\text { pribadi }\end{array}$ & $\begin{array}{ll}\text { - } & \text { Merasa sudah } \\
\text { bahagia. } \\
\text { - } \\
\text { Mendalami } \\
\text { agama sebagai } \\
\text { standar dalam }\end{array}$ & $\begin{array}{ll}\text { - } & \text { Merasa sudah } \\
\text { bahagia. } \\
\text { - } \\
\text { Mendalami agama } \\
\text { sebagai standar } \\
\text { dalam menjalani }\end{array}$ & $\begin{array}{l}\text { - Menyadari bahwa } \\
\text { beberapa orang } \\
\text { juga memiliki } \\
\text { kompetensi dalam } \\
\text { suatu bidang dan }\end{array}$ \\
\hline
\end{tabular}




\begin{tabular}{|c|c|c|c|}
\hline & $\begin{array}{l}\text { menjalani } \\
\text { kehidupan. } \\
\text { Menyadari } \\
\text { bahwa beberapa } \\
\text { orang juga } \\
\text { memiliki } \\
\text { kompetensi } \\
\text { dalam suatu } \\
\text { bidang dan } \\
\text { dapat } \\
\text { menyelesaikan } \\
\text { masalah. } \\
\text { Arti } \\
\text { kebahagiaan } \\
\text { adalah } \\
\text { kesehatan, } \\
\text { keselamatan, } \\
\text { dan keluarga. }\end{array}$ & $\begin{array}{l}\text { kehidupan. } \\
\text { - Menyadari bahwa } \\
\text { beberapa orang } \\
\text { juga memiliki } \\
\text { kompetensi dalam } \\
\text { suatu bidang dan } \\
\text { dapat } \\
\text { menyelesaikan } \\
\text { masalah. } \\
\text { - Arti kebahagiaan } \\
\text { adalah kesehatan, } \\
\text { keselamatan, dan } \\
\text { keluarga. }\end{array}$ & $\begin{array}{l}\text { dapat } \\
\text { menyelesaikan } \\
\text { masalah. } \\
\text { - Arti kebahagiaan } \\
\text { adalah kesehatan, } \\
\text { keselamatan, dan } \\
\text { keluarga. }\end{array}$ \\
\hline \multicolumn{4}{|c|}{ Dimensi Penguasaan Lingkungan } \\
\hline $\begin{array}{l}\text { Perasaan } \\
\text { menguasai dan } \\
\text { kompeten dalam } \\
\text { menangani } \\
\text { permasalahannya }\end{array}$ & $\begin{array}{ll}\text { - } & \text { Masih merasa } \\
\text { memiliki } \\
\text { kemampuan } \\
\text { untuk menjalani } \\
\text { profesinya } \\
\text { dengan } \\
\text { kapasitas yang } \\
\text { dimiliki. } \\
\text { Doa sebagai } \\
\text { jalan keluar dari } \\
\text { permasalahan. } \\
\text { Memiliki } \\
\text { kegiatan rutin } \\
\text { sehari-hari yaitu } \\
\text { memimpin } \\
\text { organisasi } \\
\text { keagamaan. }\end{array}$ & 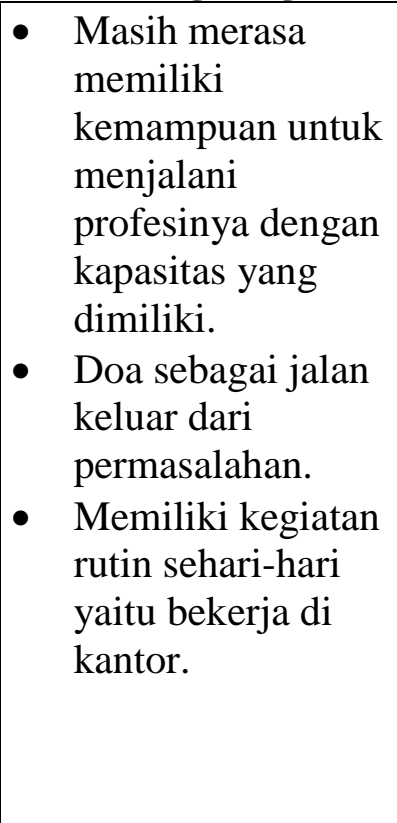 & $\begin{array}{ll}\text { - } & \text { Masih merasa } \\
\text { memiliki } \\
\text { kemampuan untuk } \\
\text { menjalani } \\
\text { profesinya dengan } \\
\text { kapasitas yang } \\
\text { dimiliki. } \\
\text { - } \\
\text { Doa sebagai jalan } \\
\text { keluar dari } \\
\text { permasalahan. } \\
\text { Memiliki kegiatan } \\
\text { rutin sehari-hari } \\
\text { yaitu mengurus } \\
\text { rumah tangga. }\end{array}$ \\
\hline $\begin{array}{l}\text { Mampu } \\
\text { mengontrol } \\
\text { kegiatan-kegiatan } \\
\text { eksternal yang } \\
\text { kompleks }\end{array}$ & $\begin{array}{l}\text { Dengan kondisi } \\
\text { fisik yang sudah } \\
\text { memasuki usia } \\
\text { lanjut, subyek } \\
\text { masih mampu } \\
\text { menjalani } \\
\text { profesinya. } \\
\text { Dapat membagi } \\
\text { waktu untuk } \\
\text { mengikuti } \\
\text { komunitas }\end{array}$ & $\begin{array}{l}\text { Dengan kondisi } \\
\text { fisik yang sudah } \\
\text { memasuki usia } \\
\text { lanjut, subyek } \\
\text { masih mampu } \\
\text { menjalani } \\
\text { profesinya. } \\
\text { Dapat membagi } \\
\text { waktu untuk } \\
\text { mengikuti } \\
\text { komunitas lansia. }\end{array}$ & $\begin{array}{l}\text { Dengan kondisi } \\
\text { fisik yang sudah } \\
\text { memasuki usia } \\
\text { lanjut, subyek } \\
\text { masih mampu } \\
\text { menjalani } \\
\text { profesinya. } \\
\text { Dapat membagi } \\
\text { waktu untuk } \\
\text { mengikuti } \\
\text { komunitas lansia. }\end{array}$ \\
\hline
\end{tabular}




\begin{tabular}{|c|c|c|c|}
\hline & $\begin{array}{l}\text { lansia. } \\
\text { - Mengikuti } \\
\text { komunitas } \\
\text { dianggap } \\
\text { mampu } \\
\text { menghilangkan } \\
\text { stress. } \\
\text { - Menyadari } \\
\text { bahwa } \\
\text { beraktivitas di } \\
\text { luar rumah } \\
\text { dapat } \\
\text { menghilangkan } \\
\text { stress. }\end{array}$ & $\begin{array}{ll}\text { - } & \text { Menyadari bahwa } \\
\text { beraktivitas di } \\
\text { luar rumah dapat } \\
\text { menghilangkan } \\
\text { stress. } \\
\text { - } \\
\text { Tidak memiliki } \\
\text { kesulitan dalam } \\
\text { mengatur tugas } \\
\text { rumah tangga, dan } \\
\text { masih memiliki } \\
\text { banyak waktu } \\
\text { untuk beraktivitas } \\
\text { di luar rumah. }\end{array}$ & $\begin{array}{ll}\text { - } & \text { Mengikuti } \\
\text { komunitas } \\
\text { dianggap mampu } \\
\text { menghilangkan } \\
\text { stress. } \\
\text { - } \text { Menyadari bahwa } \\
\text { beraktivitas di } \\
\text { luar rumah dapat } \\
\text { menghilangkan } \\
\text { stress. } \\
\text { Tidak memiliki } \\
\text { kesulitan dalam } \\
\text { mengatur tugas } \\
\text { rumah tangga, dan } \\
\text { masih memiliki } \\
\text { banyak waktu } \\
\text { untuk beraktivitas } \\
\text { di luar rumah. }\end{array}$ \\
\hline \multicolumn{4}{|c|}{ Dimensi Tujuan Hidup } \\
\hline $\begin{array}{l}\text { Menemukan } \\
\text { makna dalam } \\
\text { hidup }\end{array}$ & $\begin{array}{ll}\text { - } & \text { Spiritualitas dan } \\
\text { religiusitas } \\
\text { sebagai makna } \\
\text { hidupnya. } \\
\text { - Memiliki hidup } \\
\text { yang aman dan } \\
\text { sentosa. } \\
\text { - Menjadi lansia } \\
\text { yang berhasil, } \\
\text { dengan tidak } \\
\text { menganggur, } \\
\text { tidak } \\
\text { menyendiri dan } \\
\text { memiliki roh } \\
\text { kejiwaan }\end{array}$ & 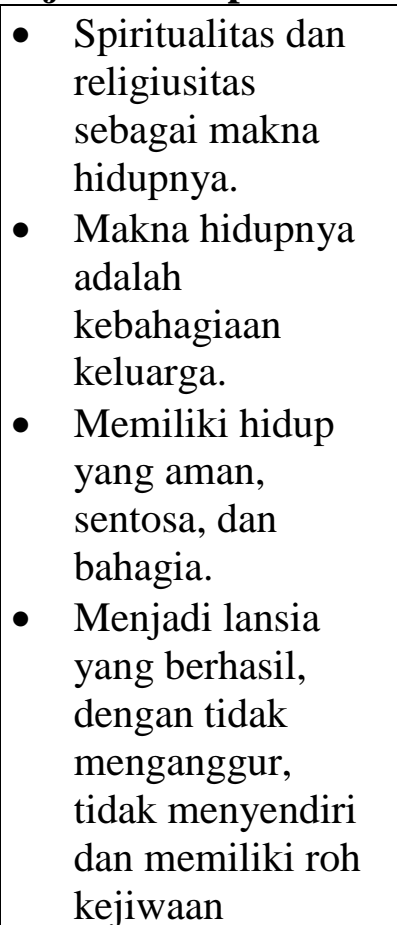 & $\begin{array}{ll}\text { - } & \text { Makna hidupnya } \\
\text { adalah } \\
\text { kebahagiaan } \\
\text { keluarga. } \\
\text { - Mengabdi pada } \\
\text { keluarga. } \\
\text { - Menjadi lansia } \\
\text { yang berhasil, } \\
\text { dengan tidak } \\
\text { menganggur, } \\
\text { tidak menyendiri } \\
\text { dan memiliki roh } \\
\text { kejiwaan }\end{array}$ \\
\hline $\begin{array}{l}\text { Menemukan } \\
\text { tujuan hidup }\end{array}$ & 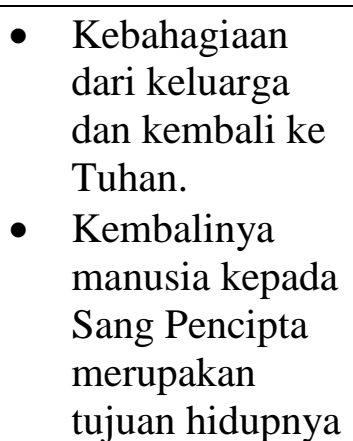 & $\begin{array}{l}\text { - Kebahagiaan dari } \\
\text { keluarga dan } \\
\text { kembali ke } \\
\text { Tuhan. } \\
\text { - Menyenangkan } \\
\text { dirinya di usia tua } \\
\text { dengan } \\
\text { melakukan hal } \\
\text { yang disukai. }\end{array}$ & $\begin{array}{l}\text { - } \text { Kebahagiaan dari } \\
\text { keluarga dan } \\
\text { kembali ke } \\
\text { Tuhan. } \\
\text { - Menyenangkan } \\
\text { dirinya di usia tua } \\
\text { dengan } \\
\text { melakukan hal } \\
\text { yang disukai. }\end{array}$ \\
\hline
\end{tabular}




\begin{tabular}{|c|c|c|c|}
\hline & $\begin{array}{l}\text { saat ini. } \\
\text { Setelah semua } \\
\text { hal dirasa sudah } \\
\text { tercapai, } \\
\text { kematian } \\
\text { dianggap } \\
\text { sebagai tujuan } \\
\text { akhirnya hidup } \\
\text { di dunia ini, } \\
\end{array}$ & & \\
\hline \multicolumn{4}{|c|}{ Dimensi Pertumbuhan Pribadi } \\
\hline $\begin{array}{l}\text { Menyadari dan } \\
\text { mengembangkan } \\
\text { potensi diri. }\end{array}$ & \begin{tabular}{|l} 
Belajar \\
sepanjang hayat \\
adalah prinsip \\
hidup, sehingga \\
sampai saat ini \\
masih terus \\
belajar. \\
Menerima kritik \\
namun tetap \\
teguh pada \\
pendiriannya. \\
Menyadari \\
potensi yang \\
dimilikinya. \\
\end{tabular} & $\begin{array}{l}\text { Belajar sepanjang } \\
\text { hayat adalah } \\
\text { prinsip hidup, } \\
\text { sehingga sampai } \\
\text { saat ini masih } \\
\text { terus belajar. } \\
\text { Menyadari } \\
\text { potensi yang } \\
\text { dimilikinya. }\end{array}$ & $\begin{array}{l}\text { Belajar sepanjang } \\
\text { hayat adalah } \\
\text { prinsip hidup, } \\
\text { sehingga sampai } \\
\text { saat ini masih } \\
\text { terus belajar. } \\
\text { Menyadari } \\
\text { potensi yang } \\
\text { dimilikinya. }\end{array}$ \\
\hline $\begin{array}{l}\text { Terbuka pada } \\
\text { pengalaman baru. }\end{array}$ & \begin{tabular}{|l} 
Menyukai hal- \\
hal yang \\
memberinya \\
pengalaman \\
baru. \\
Selalu \\
mengembangka \\
n potensi yang \\
dimilikinya.
\end{tabular} & $\begin{array}{l}\text { - Selalu } \\
\text { mengembangkan } \\
\text { potensi yang } \\
\text { dimilikinya. }\end{array}$ & $\begin{array}{l}\text { - Menyukai hal-hal } \\
\text { yang memberinya } \\
\text { pengalaman. } \\
\text { - Selalu } \\
\text { mengembangkan } \\
\text { potensi yang } \\
\text { dimilikinya. }\end{array}$ \\
\hline $\begin{array}{l}\text { Melihat kemajuan } \\
\text { diri dari waktu ke } \\
\text { waktu. }\end{array}$ & \begin{tabular}{|l|} 
Di usia senja \\
menyadari \\
bahwa \\
perbuatan harus \\
disertai dengan \\
doa. \\
\end{tabular} & $\begin{array}{l}\text { - Di usia senja } \\
\text { menyadari bahwa } \\
\text { perbuatan harus } \\
\text { disertai dengan } \\
\text { doa. }\end{array}$ & $\begin{array}{l}\text { - Di usia senja } \\
\text { menyadari bahwa } \\
\text { perbuatan harus } \\
\text { disertai dengan } \\
\text { doa. }\end{array}$ \\
\hline
\end{tabular}

\section{Dimensi Penerimaan Diri}

Berdasarkan data yang diperoleh dari ketiga lansia yang menjadi subyek penelitian, diperoleh pemahaman bahwa ketiga subyek penelitian mampu menerima dirinya dan menerima keadaan atau kondisi dirinya yang telah memasuki masa lansia.

Setiap subyek memiliki sikap positif terhadap keadaanya saat ini bahkan sudah bisa berdamai dengan keadaan masa lalunya. Meskipun setiap subyek mengakui bahwa di usianya saat ini banyak terjadi perubahan, terutama pada aspek fisik, namun masing- 
masing subyek penelitian memiliki cara tersendiri untuk mengatasi permasalahan tersebut. Mereka dapat memaknai arti kematian secara positif, yaitu sebagai suatu perjalanan yang memang harus dijalani dan dihadapi. Hal yang dilakukan untuk mempersiapkan kematian tersebut ialah dengan cara mendekatkan diri kepada Tuhan, meningkatkan keimanan dan ketakwaan kepada Tuhan YME.

\section{Dimensi Hubungan Positif dengan Orang Lain}

Hubungan positif dengan orang lain merupakan kemampuan untuk membina hubungan interpersonal yang erat dan saling percaya, saling mengembangkan pribadi satu dengan yang lain serta mampu menjalin persahabatan yang mendalam (Ryff, 1989). Seperti yang diuraikan oleh Erikson (Prawitasari, 1994), bahwa tugas perkembangan di usia lanjut adalah tercapainya integritas dalam diri. Artinya, lansia merasa bahagia dalam hubungan dirinya dengan orang lain.

Ketiga subyek penelitian merupakan lansia yang memiliki hubungan positif dengan orang lain. Baik dengan anak, cucu, saudara, para tetangga dan rekan kerja mereka. Orang yang beraktualisasi diri digambarkan memiliki rasa empati dan afeksi yang kuat terhadap manusia dan dapat memiliki cinta yang mendalam, persahabatan yang kuat, dan memiliki identifikasi yang sempurna terhadap yang lain. Membina hubungan yang erat dengan orang lain merupakan salah satu dari criterion of maturity yang dikemukakan oleh Allport (Ryff, 1989).

Menurut teori perkembangan Erikson (Ryff \& Singer, 2008) dimensi ini menekankan pada pencapaian kedekatan individu dengan orang lain, dimana semua subyek memiliki hubungan yang baik dengan keluarga, tetangga, bahkan rekan kerja. Mereka mampu membina kekerabatan yang erat.

\section{Otonomi}

Ketiga subyek penelitian merupakan pribadi yang memiliki kemandirian dalam beraktivitas. Mereka masih mampu melakukan segala macam aktivitas sehari-hari dengan kemampuannya sendiri sesuai dengan kondisi fisik mereka. Subyek mengevaluasi dirinya menggunakan standar nilai religius, dimana Tuhan Yang Maha Kuasa sebagai kekuatan terbesar dalam hidupnya.

Havigurst (Demartoto, 2006) menjelaskan bahwa orang lansia akan merasa bahagia bila mereka masih dapat melakukan banyak aktivitas. Martaniah (Demartoto, 2006) mengemukakan bahwa para lansia masih menginginkan aktivitas pergaulan dan hidup mandiri.

\section{Dimensi Penguasaan Lingkungan}

Individu yang memiliki penguasaan lingkungan adalah individu yang memiliki sense of mastery dan kemampuan untuk mengatur lingkungan, mengontrol berbagai kegiatan eksternal yang kompleks, menggunakan kesempatan-kesempatan yang ada secara efektif, mampu memilih atau menciptakan konteks yang sesuai dengan kebutuhan-kebutuhan dan nilai-nilai pribadi (Ryff, 1989).

Para subyek penelitian mampu mengontrol berbagai kegiatan yang harus dilakukannya secara mandiri. Subyek penelitian mampu menjadwal aktivitas kegiatan sehari-hari yang dilakukan dengan rutin sesuai dengan kemampuan fisik dan kebutuhannya. 


\section{Dimensi Tujuan Hidup}

Dimensi ini terkait dengan kemampuan pemahaman individu akan tujuan dan arah hidupnya. Individu dianggap baik menurut dimensi ini apabila individu tersebut memiliki kepercayaan yang dapat memberinya arti dan tujuan hidup, memiliki pemahaman yang jelas akan tujuan dan arah hidup yang dijalaninya, memiliki tujuan dan arah dalam hidup, merasakan arti dalam hidup masa kini maupun yang telah dijalani (Ryff, 1989).

Ketiga subyek penelitian memiliki perencanaan masa depan serta mampu mencapai target tersebut sehingga subyek memiliki pikiran positif bahwa dirinya masih berguna bagi orang lain dan lingkungan sekitarnya. Subyek penelitian memiliki tujuan hidup yang akan dapat dicapai jika mereka terus berusaha mencapainya. Penurunan kondisi fisik tidak menghambat subyek dalam mencapai tujuan hidupnya, mereka tetap bekerja. Mereka juga semakin mendekatkan diri kepada Tuhan, sejalan dengan penelitian Chatter \& Ellison (Amani \& Coralia, 2017) yang menemukan adanya kaitan antara keterlibatan religiusitas (religious involvement) dengan Psychological WellBeing.

Subyek penelitian merasa dirinya masih berfungsi dalam menerima kelemahan dan kesulitan yang dihadapi serta merasa mudah untuk mencapai tujuan hidupnya karena dapat menemukan kelebihan yang dimiliki. Hal ini berarti sebagian besar kaum lansia menghayati hidupnya, berfungsi dengan tinggi dan mampu mengenal kemampuan dan potensinya masing-masing sehingga dapat mencapai tujuan dalam hidup.

\section{Pertumbuhan Pribadi}

Individu akan senantiasa mengembangkan potensi dirinya dan terbuka bagi pengalaman-pengalaman baru. Individu dikatakan memiliki pertumbuhan pribadi yang baik apabila mereka sadar akan potensinya, memiliki perasaan untuk berkembang secara berkelanjutan, melihat kemajuan diri dan tingkah laku dari waktu ke waktu, berubah dengan cara yang efektif untuk menjadi lebih baik dan terbuka terhadap pengalaman-pengalaman baru (Ryff,1989).

Para lansia memiliki dimensi perkembangan diri yang tinggi, terbuka dalam pengalaman baru serta mengembangkan potensi yang dimilikinya. Para lansia tertarik dengan kegiatan seperti komunitas atau organisasi, bahkan terdapat lansia yang menjadi pengurus aktif dalam suatu organisasi. Mereka dapat berbaur dengan banyak orang, mendapatkan banyak informasi baru, pengalaman baru sehingga merasa dirinya berguna untuk orang lain karena organisasi yang mereka ikuti mayoritas pada bidang sosial atau kemanusiaan.

Dalam tahapan perkembangan milik Erikson (Santrock, 1995), secara psikologis seorang lansia berada pada tahap akhir perkembangannya, yaitu integritas dan kekecewaan (integrity versus despair). Pada tahun-tahun terakhir kehidupan, kita menoleh ke belakang dan mengevaluasi apa yang telah kita lakukan dengan kehidupan kita. Ketiga subyek penelitian menggambarkan masa lalu mereka sebagai masa yang sulit. Namun, mereka merasa mampu untuk mengatasinya sehingga mereka dapat melewati masa-masa sulit tersebut dan menjadi pribadi yang lebih baik di saat ini. Jika orang usia lanjut dapat mengenang kehidupannya dengan rasa puas, ia mengalami suatu rasa keutuhan, rasa integritas, dan kematian boleh dikatakan dapat diterima. Sebaliknya, seorang lanjut usia akan merasa putus asa bila ia merasa telah kehilangan kesempatan penting dan bila ia harus menghadapi fakta yang tak dapat dihindari bahwa baginya 
terlambatlah untuk memulai dari bawah lagi (Bradbury, 1987). Dalam penelitian yang dilakukan, ketiga subyek memandang dan merasa kehidupannya sebagai suatu yang sempurna. Mereka puas dengan segala pencapaian dan apa yang dimiliki mereka saat ini. Mereka berada dalam suatu lingkungan keluarga yang mencintai mereka dan memberikan dukungan penuh terhadap masa tua mereka, mereka juga memiliki banyak aktifitas yang dapat merangsang kreatifitas mereka, sehingga para subyek lansia ini masih aktif bergerak, beraktifitas dan bersosialisasi di lingkungannya.

\section{Peran Taman Lansia An-Naba}

Keikutsertaan dan aktivitas para subyek dalam persekutuan juga terlihat berpengaruh bagi kehidupan lansia. Ketiga lansia yang menjadi subyek penelitian menekankan, bahwa persekutuan lansia mempunyai peran dalam kehidupan mereka. Mereka menjadi lebih mempersiapkan diri menghadapi berbagai perubahan usia lanjut yang menghampiri mereka. Disamping itu, persekutuan tersebut memiliki peran dalam mengisi waktu kosong dan tentu saja semakin mendekatkan diri mereka kepada Tuhan. Persekutuan lansia merupakan suatu bentuk dukungan sosial berupa layanan spiritual bagi para lansia. Menurut Beyene (Gunarsa, 2004), dukungan spiritual berperan dalam membangun kembali kesejahteraan diri pada lansia. Spiritualitas dan agama diketahui berperan penting dalam kehidupan banyak lansia dan keduanya diketahui berkorelasi positif dengan kesejahteraan (Hoyer \& Roodin, 2003), dimana psychological well-being atau kesejahteraan psikologis merupakan salah satu aspeknya. Bagi lansia menurut McFadden (Hoyer \& Roodin, 2003), spiritualitas merupakan satu cara untuk menghubungkan diri mereka dengan Tuhan. Menurut Pargament (Hoyer \& Roodin, 2003), agama membantu individu untuk mendapat makna, perasaan berguna, dan kerangka kerja yang runtut untuk hidup mereka. Agama terus dikaitkan dengan panjang umur, peningkatan status kesehatan (contohnya, reduksi risiko penyakit kardiovaskular dan hipertensi yang lebih rendah), harga diri lebih rendah, dan peningkatan psychological well-being (Hoyer \& Roodin, 2003).

Kaum lansia di taman lansia An-Naba yang memiliki Psychological Well-Being tinggi dan memiliki seluruh dimensi yang tinggi yang berarti telah mampu menerima keadaan dirinya sebagai orang lansia dan mampu menerima keterbatasannya serta kelebihan yang dimiliki.

Para lansia tidak takut untuk menyampaikan pendapatnya dimanapun mereka berada, karena dengan begitu mereka dapat berpartisipasi di lingkungan. Walaupun kekuatan fisik sudah mulai menurun, mereka tetap dapat berbagi waktu dan tenaganya untuk bekerja dan mengurus keluarganya bahkan masih aktif di organisasi. Mereka telah mengetahui kapan ketika fisiknya mulai lemah, dan mereka akan berhenti bekerja dan melanjutkannya ketika telah merasa membaik. Semua pekerjaan yang menjadi tanggung jawabnya tetap dilaksanakan sesuai dengan kondisi tubuhnya.

\section{KESIMPULAN}

1. Ketiga subyek memiliki psychological well-being dan berhasil melalui tahapan perkembangannya, sehingga dapat dikatakan mencapai aktualisasi diri di masa tuanya. Hal ini terlihat dari masing-masing dimensi yang digambarkan oleh para subyek.

2. Aktivitas di persekutuan lansia tersebut memiliki pengaruh bagi subyek. Persekutuan lansia mampu memberikan pandangan yang positif bagi mereka terhadap diri mereka, meningkatkan kualitas hubungan mereka dengan sesama 
anggota, serta mampu meningkatkakan kualitas mereka dengan Tuhan sehingga mereka memiliki tujuan hidup di masa tua mereka.

3. Semua dimensi dalam Psychological Well-Being tergolong tinggi, dimensi paling dominan yang dimiliki pasien adalah otonomi, ini menunjukkan para pasien tidak bergantung pada orang lain dan dapat mengambil keputusan serta tindakannya sendiri. Sementara item dimensi yang kurang dominan yang dimiliki lansia adalah dimensi penerimaan diri.

\section{DAFTAR PUSTAKA}

Amani, G. T., \& Coralia, F. (2017). Studi Deskriptif Mengenai Psychological WellBeing pada Pasien Diabetes Mellitus Tipe 2 di RSUD Soreang. Psikologi, Vol. 3, No. 2, pp. 830-837.

Asfriyati. (2003). Upaya Pembinaan dan Pelayanan Kesehatan Usia Lanjut. USU Digital Library. Diambil pada tanggal 18 Agustus 2018 dari http://library.usu.ac.id/download/fkm/fkm-asfriyati.pdf.

Badan Pusat Statistik. (2008). Indeks Pembangunan Manusia 2006-2007. Jakarta: Badan Pusat Statistik.

Badan Pusat Statistik. (2015). Statistik Penduduk Lanjut Usia 2014. Jakarta: Badan Pusat Statistik.

Bradbury, W. (1987). Perilaku Manusia Masa Dewasa. Jakarta: Tira Pustaka.

Demartoto, A. (2006). Pelayanan Sosial Non Panti Bagi Lansia: Suatu Kajian Psikologis. Surakarta: Sebelas Maret University Press.

Diener, E., \& Eid, M. (2006). Handbook of multimethod measurement in psychology. Washington, DC: American Psychological Association.

Gunarsa, S. D. (2004). Dari Anak Sampai Usia Lanjut: Bunga Rampai Psikologi Anak. Jakarta: Gunung Mulia.

Herman. (2014). Depresi, Penyebab Tingginya Angka Bunuh Diri di Gunungkidul. Beritasatu edisi 15 September 2014. Diambil pada tanggal 18 Agustus 2018 dari http://www.beritasatu.com/kesra/210021-depresi-penyebab-tingginya-angkabunuh-diri-di-gunungkidul.html.

Hoyer, W. J., \& Roodin, P. A. (2003). Adult Development and Aging. New York City, NY: McGraw Hill.

Kementerian Kesehatan. (2013). Riset Kesehatan Dasar Tahun 2013. Jakarta. Kementerian Kesehatan.

Kementerian Kesehatan. (2014). Profil Kesehatan Kabupaten Gunungkidul Tahun 2013.

$\begin{array}{llllll}\text { Diambil pada } & \text { tanggal } & 18 & \text { Agustus } & 2018 & \text { dari }\end{array}$


http://www.depkes.go.id/resources/download/profil/PROFIL_KAB_KOTA_2013/ 3403_DIY_Kab_Gunung_Kidul_2013.pdf.

Kementerian Kesehatan. (2015). Pelayanan dan Peningkatan Kesehatan Usia Lanjut. Diambil pada tanggal 30 Agustus 2018 dari http://www.depkes.go.id/pdf.php?id=15052700010.

Kusumo, H. J. (2018). Memprihatinkan! 18.420 Lansia di Gunungkidul Hidup Terlantar. Jateng Pos edisi 16 Januari 2018. Diambil pada tanggal 18 Agustus 2018 dari http://www.jatengpos.com/2018/01/memprihatinkan-18-420-lansia-digunungkidul-hidup-terlantar-885144.

Mohanty, S., Gangil, O. P., \& Kumar, S. (2012). Instrumental Activities of Daily Living and Subjective Wellbeing in Elderly Persons Living in Community. Indian Journal of Gerontology, Vol. 26, No. 2, pp. 193-206.

Prawitasari, J. E. (1994). Aspek Sosio-Psikologis Lansia di Indonesia. Buletin Psikologi, No. 1, pp. 27-34.

Presiden RI. (1998). Undang-Undang Republik Indonesia Nomor 13 Tahun 1998 Tentang Kesejahteraan Lanjut Usia.

Presiden RI. (2009). Undang-Undang Republik Indonesia Nomor 36 Tahun 2009 Tentang Kesehatan.

Putri, A. (2018). Belasan Ribu Lansia Terlantar Meski Angka Kemiskinan Menurun. Sorot Gunungkidul edisi 31 Januari 2018. Diambil pada tanggal 18 Agustus 2018 dari http://gunungkidul.sorot.co/berita-95490-belasan-ribu-lansia-terlantar-meskiangka-kemiskinan-menurun.html.

Ridarineni, N. (2013). Lansia Terlantar di DIY Meningkat 16,79 Persen. Republika edisi 23 Februari 2013. Diambil pada tanggal 18 Agustus 2018 dari https://www.republika.co.id/berita/nasional/daerah/13/02/23/mioild-lansiaterlantar-di-diy-meningkat-1679-persen.

Ryff, C.D. (1989). Happiness is Everything or is it? Exploration on the meaning of psychological well-being. Journal of Personality and Social Psychology, No. 57, pp. 1069-1081.

Ryff, C. D., \& Singer, B. H. (2008). Know thyself and become what yo are: A eudaimonic approach to psychological well-being. Journal of Happiness Studies, 9, pp. 13-39.

Santrock, J. W. (1995). Perkembangan Masa Hidup (5th eds)(Terjemahan Juda Damanik \& Achmad Chusairi). Jakarta: UI Press.

Sucahyo, N. (2017). Gunungkidul dan Bunuh Diri: Antara Mitos dan Depresi. VOA Indonesia edisi 22 November 2017. Diambil pada tanggal 30 Agustus 2018 dari 
https://www.voaindonesia.com/a/gunungkidul-dan-bunuh-diri-antara-mitos-dandepresi/4128916.html.

Taher, A. (2015). Harmonisasi Sistem Pendidikan Kedokteran dengan Pelayanan Kesehatan dalam Konsep Academic Health System (AHS). Kementerian Kesehatan RI. Diambil pada tanggal 18 Agustus 2018 dari http://fk.ugm.ac.id/wpcontent/uploads/2015/04/AHS-2015-Prof-Akmal-Dirjen-BUK.pdf.

Vaznoniene, G. (2016). Socio-Demographic Factors of Elderly Subjective Wellbeing in Lithuania. Proceedings of the 2016 International Conference "Economic Science for Rural Developmen” No. 43, Jelgava, LLU ESAF, 21-22 April 2016, pp. 125132. 